\title{
Profile of caregivers of Alzheimer's disease patients attended at a reference center for cognitive disorders
}

\author{
Marco Antonio Moscoso ${ }^{1,2}$, Rita de Cássia Gomes Marques ${ }^{1,2}$, \\ Salma Rose Imanari Ribeiz ${ }^{1,2}$, Lysandra dos Santos ${ }^{1,2}$, Diana Moitinho Bezerra ${ }^{2}$, \\ Wilson Jacob Filho ${ }^{1,3}$, Ricardo Nitrini, ${ }^{1,4}$, Cássio Machado de Campos Bottino ${ }^{1,2}$
}

\begin{abstract}
This is a study on burden of caregivers of patients with Alzheimer's disease attended at a Reference Center for Cognitive Disorders. Objective: To evaluate the profile and burden on caregivers of patients with Alzheimer's disease attended at a Reference Center for Cognitive Disorders. Methods: We collected demographic information and data on the relationship with the patient from caregivers, and measured burden with the Zarit scale. The patients were evaluated with the following scales: the Cambridge Cognitive Test (CAMCOG); Mini Mental State Examination, the Neuropsychiatric Inventory for neuropsychiatry symptoms, and Functional Activities Questionnaire - FAQ for functional impairment. Results: Of the 31 caregivers, 77.4\% were female, predominantly, and daughters, having a mean age of 58.6 years, educational level of 8.1 years, $70 \%$ of caregivers co-resided with the patient and $71 \%$ did not work. The mean time as a caregiver was 3 years. Twenty-seven percent of the caregivers presented mild to severe burden. The variables presenting significant association with caregiver burden were scores on the NPI and CAMCOG. Conclusion: The social demographic characteristics of the sample were similar to those of studies performed in other countries. The average time as a caregiver and the frequency of caregivers with mild to intense burden were lower than those reported in international studies. Neuropsychiatric symptoms and severity of cognitive decline were the main factors associated to burden in this sample of mostly mild to moderate demented AD patients. Further studies are necessary to verify whether the burden is indeed less intense in our milieu.
\end{abstract}

Key words: Alzheimer's disease, caregivers, burden, Zarit scale, neuropsychiatric symptoms, behavioral symptoms, psychotic symptoms.

Perfil dos cuidadores de pacientes com doença de Alzheimer atendidos em centro de referência em distúrbios cognitivos

Resumo - Trata-se de um estudo sobre a sobrecarga do cuidador dos pacientes com doença de Alzheimer atendidos em Centro de Referência em Distúrbios Cognitivos. Objetivo: Avaliar o perfil e a sobrecarga do cuidador dos pacientes com doença de Alzheimer atendidos em Centro de Referência em Distúrbios Cognitivos. Método: Foram obtidos dados demográficos do cuidador e sobrecarga de acordo com a Escala de Sobrecarga de Zarit. Os pacientes foram avaliados com os seguintes testes e escalas: Teste Cognitivo Cambridge (CAMCOG); MiniExame do Estado Mental; Inventário Neuropsiquiátrico (NPI), para a presença de sintomas neuropsiquiátricos; e o Questionário de Atividades Funcionais (QAF), de Pfeffer, para o comprometimento funcional. Resultados: Os 31 cuidadores eram predominantemente do sexo feminino, filhas, idade média 58,6 anos, escolaridade média de 8,1 anos; $70 \%$ dos cuidadores moravam com o paciente; $71 \%$ não trabalhavam. $O$ tempo médio como cuidador foi de 3 anos. Vinte e sete por cento dos cuidadores apresentavam sobrecarga de intensidade leve a intensa. As variáveis que apresentaram associação significativa com a sobrecarga do cuidador foram os escores do NPI e do

${ }^{1}$ CEREDIC (Reference Center for Cognitive Disorders); Clinicas Hospital of the School of Medicine of the University of São Paulo. ${ }^{2}$ PROTER (Old Age Research Group), Institute of Psychiatry - Clinicas Hospital of the School of Medicine of the University of São Paulo. ${ }^{3}$ Department of Internal Medicine, School of Medicine of the University of São Paulo. ${ }^{4}$ Department of Neurology, School of Medicine of the University of São Paulo

Marco Antonio Moscoso - Rua Dr. Ovídio Pires de Campos 785 / 3o andar / CEAPESQ/ sala 14 - 05403-010 São Paulo SP - Brazil. E-mail: mmaparicio@ hotmail.com.

Received 07/27/2007. Received in final form 08/11/2007. Accepted 10/29/2007. 
CAMCOG. Conclusão: As características sociodemográficas dos cuidadores foram semelhantes às de estudos feitos em outros países. Entretanto, sobrecarga foi menos freqüente do que em estudos internacionais. A intensidade dos transtornos neuropsiquiátricos e a gravidade do declínio cognitivo foram os principais fatores associados à sobrecarga nesta amostra constituída principalmente por pacientes com DA, com demência leve a moderada. Mais estudos são necessários para verificar se a sobrecarga do cuidador é menos intensa em nosso meio.

Palavras-chave: doença de Alzheimer, cuidador, sobrecarga, escala Zarit, sintomas neuropsiquiátricos, comportamento, sintomas psicóticos.

Alzheimer's disease is a neurodegenerative illness characterized by a progressive decay of mental and physical capacity, increasing dependence and functional incapacity. ${ }^{1}$

According to the Alzheimer's Association in the USA, 1996, seventy per cent of patients with AD are cared for at home by friends and relatives.

In the literature, there are several definitions for the term "caregiver", but that proposed by Badia et al. ${ }^{2}$ embraces the caregiver's most typical characteristics. These authors define the caregiver as a person who helps with the basic and daily instrumental life necessities for most of the time, without receiving pecuniary return for this activity. ${ }^{2}$

The concept of burden appeared in the early sixties but it was only in the early eighties that became the focus of health professionals. Burden can be defined as the sum of physical, psychological, social and financial problems which arise among members of the family or people who assist the ill elderly. ${ }^{3}$

Montgomery et al. ${ }^{4}$ define caregivers' burden using the concept of objective burden which refers to practical problems associated with special care, such as continuous nursing care. However, subjective burden according to the same author is also called tension where this refers to the caregiver's emotional reaction (e.g. low self esteem, anxiety and depression). ${ }^{4}$

Some epidemiological studies have demonstrated that psychiatric disorders, especially anxiety and mood disorders, are systematically more prevalent in families that take care of patients with Alzheimer's disease than in the general population. ${ }^{5}$

Several studies refer to psychiatrics disorders as the most important consequences of being a caregiver. Besides these disorders, there are significant physical health repercussions, an increase in social isolation and aggravation of the economical situation. ${ }^{6-8}$

In our daily practice we observe that caregivers, after some time performing this activity, frequently present physical and psychiatric symptoms. This condition is known as The Caregiver Syndrome and is characterized by depression, tiredness, anxiety, sleep disorder, irritability, isolation, loneliness, self blame, memory and concentration difficulties, motivation loss, low self-esteem, besides cardiovascular, digestive, low immunity and metabolic

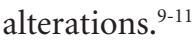

It is important to point out that the caregivers, even the symptomatic, do not seek professional treatment and in most cases their condition goes undiagnosed. ${ }^{12}$

Therefore, a need has been identified to improve the qualitative evaluation of caregivers' burden in order to diagnose and treat any mental and/or physical disorders that might arise.

To improve both evaluation and treatment of caregivers, there are appropriate instruments to evaluate the burden: the Caregiver's Effort Index, described by Vitaliano et al., ${ }^{13}$ and the Caregiver's Burden Scale or Zarit Scale. ${ }^{14}$ The latter is the most used instrument to measure caregiver burden. The Zarit Scale is a scale that covers the caregiver's health, psychological well being, finances, social life and relationship between caregiver and patient. The Brazilian version has been validated for use in Brazil by Scazufca. ${ }^{15}$

With regard to the setting of our studies, the only publication in Brazil to date on the impact of elderly with dementia on caregivers was conducted by Garrido and Menezes, ${ }^{16}$ who evaluated 49 people from a psycho geriatric service from São Paulo city.

\section{Objective}

The purpose of this study is to evaluate the profile of caregivers of Alzheimer's patients, observed at the reference center ("CEREDIC" - Clinicas Hospital Cognitive Reference Center/FMUSP), describing social demographic data such as gender, age, education level, professional activity, degree of similarity, and time as a caregiver, as well as to evaluate the burden of these caregivers according to the Zarit Scale and to investigate the association of these scores with results of cognitive tests, functional scales and caregiver characteristics.

\section{Methods}

The sample consisted of 31 unpaid familial caregivers of Alzheimer's patients from CEREDIC, as defined by Badia et al. ${ }^{2}$ This service has attended patients referred by the Psychiatric, Geriatric and Neurology outpatient units at Clinics Hospital/FMUSP with the purpose of investigating 
and diagnosing their cognitive disorders, since November 2003. The included patients are drawn from among the first 36 patients diagnosed with AD, according to DSMIV $^{17}$ and NINCDS-ADRDA ${ }^{18}$ criteria, in CEREDIC. AD patients were classified by dementia severity according to their MMSE scores: patients with 0 to 10 MMSE scores were considered severely demented, those scoring from 11 to 20 were considered moderately demented and with scores from 21 to 30 , mildly demented.

The information obtained was gathered at the first interview with the relatives and patients. All subjects agreed to participate in the study. A questionnaire on the caregiver's demographic data was applied including gender, age, educational level, professional activity, degree of similarity, whether they co-resided with the patient, and time spent as caregiver. The burden of this activity was measured using the Burden Scale by Zarit et al. ${ }^{14}$ and the severity of Burden was defined as scores higher than 46 points on the scale.

In addition, the following scales were used to aid patient diagnosis: CAMCOG (Cambridge Cognitive Test) ${ }^{19}$ and the MMSE (Mini-Mental State Exam) ${ }^{20}$ for cognitive evaluation, the NPI (Neuropsychiatry Inventory) ${ }^{21}$ to evaluate behavioral symptoms, and finally the FAQ (Functional
Activities Questionnaire) $)^{22}$ to evaluate functional compromise. Patients' final diagnoses were established over the course of up to 3 visits to the CEREDIC.

Data analysis was performed with the SPSS 14.0 for Windows program. We present descriptive statistics, with mean and standard deviation. Comparison between the groups. divided according to burden level, was made using the Student $t$ test. Regression analysis was performed with the score of the Zarit scale as the dependent variable, and age, gender, educational level, time as caregiver, MMSE, NPI, CAMCOG and FAQ as independent variables. To evaluate the linear regression model, the $\mathrm{R}$ squared change was used. The change in the $\mathrm{R} 2$ statistic is produced by adding or deleting an independent variable. Large R2 change associated indicates that the variable is a good predictor of the dependent variable. The significance level adopted for all tests was $\mathrm{p}<0.05$.

\section{Results}

Of the $31 \mathrm{AD}$ patients included in the present study, 4 $(12.9 \%)$ were classified as severely demented, $22(71 \%)$ as moderately demented, and 5 (16.1\%), as mildly demented. Considering the whole sample, $87.1 \%$ of the $\mathrm{AD}$ patients

Table 1. Tests and scales applied in AD patients and caregivers.

\begin{tabular}{lccccc}
\hline & N & Mean & Std. Dev. & Minimum & Maximum \\
\hline CAMCOG & 31 & 52.44 & 13.63 & 25 & 79 \\
NPI & 31 & 34.97 & 25.64 & 4 & 117 \\
MMSE & 31 & 15.55 & 5.39 & 2 & 27 \\
PFEFFER & 31 & 17.45 & 8.45 & 3 & 30 \\
ZARIT & 31 & 31.77 & 16.95 & 6 & 72 \\
\hline
\end{tabular}

CAMCOG: Cambridge Cognitive Test; NPI: Neuropsychiatric Inventory; MMSE: (Mini-Mental State Exam); PFFEFER/FAQ: Functional Activities Questionnaire; ZARIT: Caregiver's Burden Scale or Zarit Scale.

Table 2. Demographic and clinical characteristics of caregiver groups with and without burden (mean and standard deviation).

\begin{tabular}{lccc}
\hline & $\begin{array}{c}\text { Without Burden } \\
\mathbf{N}=\mathbf{2 4}\end{array}$ & $\begin{array}{c}\text { With Burden } \\
\mathbf{N}=\mathbf{7}\end{array}$ & $\begin{array}{c}\text { Student } \mathbf{t} \text { test } \\
\text { and } \mathbf{p} \text { value }\end{array}$ \\
\hline Age & $58.33(10.6)$ & $59.71(13.3)$ & $\mathrm{t}=0.29 \mathrm{p}=0.78$ \\
Educational level & $7.50(3.87)$ & $10.14(8.11)$ & $\mathrm{t}=-1.22 \mathrm{p}=0.24$ \\
Timecaregiving (years) & $2.50(1.39)$ & $4.50(3.68)$ & $\mathrm{t}=-2.06 \mathrm{p}=0.05$ \\
CAMCOG & $51.96(16.63)$ & $33.29(18.30)$ & $\mathrm{t}=2.56 \mathrm{p}=0.01$ \\
NPI & $26.92(22.17)$ & $62.57(33.24)$ & $\mathrm{t}=-3.33 \mathrm{p}=0.00$ \\
MMSE & $16.54(4.90)$ & $12.14(6.01)$ & $\mathrm{t}=1.99 \mathrm{p}=0.06$ \\
PFFEFER & $15.58(8.28)$ & $23.86(5.79)$ & $\mathrm{t}=-2.46 \mathrm{p}=0.02$ \\
\hline
\end{tabular}

CAMCOG: Cambridge Cognitive Test; NPI: Neuropsychiatric Inventory; MMSE: Mini-Mental State Exam; PFFEFER: Functional Activities Questionnaire. 
Table 3. Coefficients of linear regression of ZARIT scale by NPI and CAMCOG.

\begin{tabular}{lcc}
\hline & Beta & p value \\
\hline NPI & 0.414 & 0.012 \\
CAMCOG & -0.380 & 0.020 \\
\hline
\end{tabular}

NPI: Neuropsychiatric Inventory; CAMCOG: Cambridge Cognitive Test.

were classified as mild to moderately demented, according to their general cognitive status. Out of 31 caregivers of patients with Alzheimer's disease, $77.4 \%$ were female. The mean age of the caregivers was $58.6( \pm 11.1)$ years, with mean schooling of $8.1( \pm 5.1)$ years. Sixty seven percent of the caregivers co-resided with the patient. Regarding professional activity, $29.0 \%$ held an outside job and $71.0 \%$ were dedicated fulltime to the care of the patient. In regard to the degree of kindred of the caregiver, the most frequent relationship was that of daughter at $61.3 \%$, followed by husband at $16.1 \%$, wife at $9.7 \%$, sister at $6.5 \%$ and others at $6.4 \%$. The average time as caregiver was $3.0( \pm 2.2)$ years. The scores from the tests and scales applied to the patients with Dementia are described in Table 1.

Concerning level of burden measured by the Zarit scale, a total of $27 \%$ of caregivers presented a burden between mild and intense, corresponding to scores higher than 46 points. Table 2 below describes the level of caregiver burden according to the Zarit scale, comparing social and demographic variables of the caregivers along with tests and scales applied to the patients.

In the analysis of linear regression the only variables that demonstrated significant association with the Zarit scale were the NPI and the CAMCOG (Table 3).

Employing this model, we were able to explain $43.6 \%$ of the variation of scores from the Zarit scale. Significant association of the Zarit scale with other variables such as age, gender, educational level, time as caregiver, MMSE and FAQ by Pfeffer were not observed.

\section{Discussion}

The results found in the present study are similar in many aspects with those found in several other studies on the subject. In the sample investigated, the 31 caregivers of patients were predominantly women $(77.4 \%)$, a similar ratio to that observed by several earlier studies showing rates of between $63.4 \%$ and $87.0 \%$ of female caregivers. ${ }^{2,8,16,23}$ It is important to note that, in general, caregivers of the female gender present greater indexes of burden, depression and social isolation..$^{22,25,26,27}$ In the present study, the mean age of the caregivers was 58.6 years, while studies by Carrasco et al. ${ }^{7}$ reported 56.0 years, 68.0 years $^{2}, 51.3$ years $^{16}, 54.6$ years $^{8}$, and 59.0 years $^{23}$. Therefore, the mean age of caregivers in several other studies, including ours, are similar falling within the sixth and the seventh decade of life. Hinton et al. ${ }^{28}$ noted that younger caregivers are more prone to stress and depression than older caregivers.

With regards to the degree of kindred, our study observed that of daughter as being the most frequent (61.3\%), followed by husband. In the majority of studies reviewed including those by Schene, ${ }^{29}$ Carrasco et al. ${ }^{7}$ and Diaz et al., ${ }^{23}$ wives were more frequent than husbands. Croog et al. ${ }^{30}$ evaluated the differences between wives and husbands as caregivers and verified that wives were more vulnerable to overload than husbands. Hypotheses for this difference include: the greater tendency of women to report, their physical and psychological symptoms, and that wives and husbands as caregivers differ with regard to the concept and role of caregiver. Finally, female caregivers can often have longer daily contact with the patient and can therefore be more affected due to persistent stress factors. Regarding physical, psychological and burden problems, studies suggested that women, and particularly daughters, are a high risk group as caregivers presenting higher vulnerability to these problems.

The average education level of our caregivers was 8.1 $( \pm 5.1)$ years of schooling. Garrido and Menezes ${ }^{16}$ stated that their caregivers had 8 or more years of education while Alonso et al. ${ }^{8}$ did not report mean education level in their study. They had only reported that $70.2 \%$ of the caregivers either had not attended school or had only attended primary school. However, Badia et al. ${ }^{2}$ stated that $39 \%$ of their caregivers had received schooling, and that $25.4 \%$ held either part-time or full-time jobs, while $25.4 \%$ were pensioners. On the other hand, the studies by Diaz et al. ${ }^{23}$ and Carrasco et al. ${ }^{7}$ did not include education level of the caregivers or whether they held jobs.

The education level of the caregivers in our sample was in line with that found in the Brazilian study by Garrido and Menezes. ${ }^{16}$ It might be valuable in future studies to evaluate caregivers with little schooling, in order to verify whether education level has any influence on the burden of the caregiver. Our regression analysis found no significant association between burden and education level. However, an earlier study showed higher levels of education and financial situation to be associated with lesser levels of stress. ${ }^{31}$ Another important finding on caregivers was that $67.7 \%$ of them co-resided with the patient, in contrast to the study of Garrido and Menezes ${ }^{16}$ which reported a rate of $81.6 \%$. This difference may be related to the higher severity of the dementia syndrome, for the mean score on the MMSE was 12.2 in the cited study compared to 15.5 in the present sample, largely comprising $(87.1 \%)$ patients with mild to moderate dementia. As the dementia syndrome 
aggravates, the patient becomes more dependent on the caregiver, leading to the caregiver residing full time with the patient. All studies observed that the physical and psychological symptoms of the caregiver, with regards to frequency and intensity, are closely linked to the time spent carrying out the activity of caregiver whereby the longer spent as caregiver, the greater the symptoms and burden evidenced. ${ }^{23}$

The literature reviewed suggested that caregiver burden was associated with many factors, including characteristics of the patient (severity and duration of dementia, behavioral problems and difficulties with daily activities), variables of the caregiver (age, tasks assigned to the caregiver, religious beliefs, ability to solve problems, ability to perceive illness) and variables related to the environment (financial resources, social support, quality of relationship in the past). Although, in the present sample, cognitive, functional impairment, as well as behavioral disturbances of the patients, have been cited as the variables most related to higher burden, many studies, including the present work, have not identified a simple relationship between severity of dementia and burden of the caregiver. Thus, the burden seems to be a product of the dynamic interaction between objective external stressors and subjective perceptions by the caregivers concerning the patients with dementia. Over the long term treatment of Dementia, the welfare of caregivers must be considered together with the treatment of the patient's illness, not overlooking the fact that, frequently, caregivers face social, emotional, physical and financial losses, which become more and more significant as the patients' illness progresses. Therefore, identifying factors that contribute to caregivers' burden can pave the way for future studies that evaluate specific stress reducing interventions for the caregiver of patients with dementia and Alzheimer. Further studies are warranted to ascertain whether the lesser burden observed in our sample reflected the relatively low level of dementia severity, sample bias, or cultural characteristics of our population.

\section{References}

1. Paleo Diaz N, Rodríguez Paleo L. Por qué cuidar a los cuidadores de pacientes con enfermedad de Alzheimer? www. geriatrianet.com 2005;7:13-17.

2. Badia LX, Suriñach LN, Gamisans RM. Calidad de vida, tiempo de dedicación y carga percibida por el cuidador principal informal del enfermo de Alzheimer. Aten Primaria 2004;34:170-177.

3. George LK, Gwyther LP. Caregiver well-being: a multidimensional examination of family caregivers of demented adults. Gerontology 1986;26:253-259.
4. Mongomery RJV, Hooyman NR. Caregiving and the experience of subjective burden. Fam Relations 1985;1:151-158.

5. Cochrane JJ, Goering PN, Rogers JM. The mental health of informal caregivers in Otario: an epidemiological survey. Am J Public Health 1997;87:2002-2007.

6. Rodríguez MI, Carrasco MA, García MM, Gutiérrez Cuadra P, Gonzalo Jiménez E, López Fernandez LA. Cuidadores familiares de personas com enfermedad neurodegenerativa: perfil, aportaciones e impacto de cuidar. Aten Primaria 2000;26: 139-144.

7. Carrasco MM, Ballesteros RJ, Ibarra GN, et al. Sobrecarga del cuidador de pacientes com enfermedad de Alzheimer y distrés psíquico. Uma asociación relegada em la valoración de las demências. Actas Esp Psiquiatr 2002;30:201-206.

8. Alonso BA, Garrido BA, Diaz PA, Casquero RR, Riera PM. Perfil y sobrecarga de los cuidadores de pacientes com demencia incluidos em el programa ALOIS. Aten Primaria 2004;33:61-68.

9. Perez TMJ, Abanto AJ, Labarta MJ. El síndrome del cuidador en los procesos com deterioro cognoscitivo (demência). Aten Primaria 1996;18:194-202.

10. Megido MJ, Espinas J, Carrasco RM, Copetti S, Caballé E. La atencion de los cuidadores del paciente com demência. Aten Primaria 1999;23:493-495.

11. López MJ. Efectos positivos de um estresor crônico. El cuidador de un enfermo con demencia.Congreso Virtual. Interpsiquis.Universidad de Madrid. Facultad de psicologia. Espana. III. 2000.

12. Díez Espino J, Redondo Valdivielso ML, Arroniz Fernández de Gaceo C, Giacchi Urzainqui A, Zabal C, Salaberri Nieto A. Malestar psíquico em cuidadores familiares de personas confinadas em su domicilio. MEDIFAM 1995;3:124-130.

13. Vitaliano PP, Russo J, Young HM, Teri L, Maiuro RD. Predictors of burden in spouse caregivers of individuals with Alzheimer's disease. Psychol Aging 1991;6:392-402.

14. Zarit SH, Reever KE, Bach-Peterson J. Relatives of the impaired elderly: correlates of feeling of burden. Gerontologist 1980;20:649-655.

15. Scazufca, M. Versão brasileira da escala Burden Interview para avaliação de sobrecarga em cuidadores de indivíduos com doenças mentais. Rev Bras Psiquiatr 2002;24:12-17.

16. Garrido R, Menezes PR. Impacto em cuidadores de idosos com demência atendidos em um serviço psicogeriátrico. Rev Saúde Pública. 2004;38:835-841.

17. American Psychiatric Association. Diagnostic and statistical manual of mental disorders (DSM-IV). Fourth ed. Washington (DC): American Psychiatric Association; 1994:143-147.

18. McKhann G, Drachman D, Folstein M, Katzman R, Price D, Stadlan EM. Clinical diagnosis of Alzheimer's disease: report of the NINCDS-ADRDA Work Group under the auspices of Department of Health and Human Services Task Force on Alzheimer's Disease. Neurology. 1984;34:939-944.

19. Roth M, Tym E, Mountjoy CO, et al. CAMDEX: a standard- 
ized instrument for the diagnosis of mental disorders in the elderly with special reference to the early detection of dementia. Br J Psychiatry 1986;149:698-709.

20. Folstein MF, Folstein SE, McHugh PR. Mini Mental State: a practical method for grading the cognitive state of patients for the clinician. J Psychiatr Res 1975;12:189-198.

21. Cummings JL, Mega M, Gray K, Rosenberg-Thompson S, Gornbein J. The Neuropsychiatric Inventory: comprehensive assessment of psychopathology in dementia. Neurology 1994;44:2308-2314.

22. Pfeffer RI, Kurosaki TT, Harrah CH, Chance JM, Filis S. Measurement of functional activities in older adults in the community. J Gerontol 1982;37:323-329.

23. Diaz PN, Rodriguez PL. Por que cuidar a los cuidadores de pacientes con enfermedad de Alzheimer. www.geriatrianet. com 2005;7:1-9.

24. Schultz R, Willianson GM. A 2-year longitudinal study of depression among Alzheimer caregivers . Psychol Aging 1991;6: 569-578.

25. Rankin ED, HAUT MW, Keefover RW. Clinical assessment of family caregivers in dementia. Gerontologist 1992;32:813-821.
26. Chou KR, Lamontagne LL, Hepworth JT. Burden experienced by caregivers of relatives with dementia in Taiwan. Nur Res 1999;48:206-214.

27. Gallicchio L, Siddiqui N, Langenberg P. Gender differences in burden and depression among informal caregivers of demented elders in the community. Int J Geriatr Psychiatry 2002;17:154-163.

28. Hinton L, Haan M, Geller S, Mungas. Neurosychiatric Symptoms in latino Elders with Dementia or cognitive Impairment without Dementia and factors that modify their association with caregiver depression. Gerontologist 2003;43:669-677.

29. Schene AH. Objective and subjective dimensions of family burden: towards an integrative framework for research. Soc Psychiatry Psychiatr Epidemiol 1990;25: 289-297.

30. Croog SH, Sudilovsky A, Burelenson J, Baurne RB. Vulnerability of husband and wife caregivers of Alzheimer disease patients to caregiving stressors. Alzheimer Dis Assoc Disord 2001;4:201-210.

31. Brody EM, Litvin SJ, Hoffman C. Marital status of caregiving daughters and co- residence with dependent parents. Gerontologist 1995;25:78-85. 